Author's copy. Appeared in: Nørskov, M., Seibt J., Quick O. 2020.

Culturally Sustainable Social Robotics-Proceedings of Robophilosophy 2020, 611-616. Series Frontiers of AI and Its Applications, IOS Press, Amsterdam. doi:10.3233/FAIA200968

\title{
Between Luther and Buddhism: Scandinavian Creation Theology and Robophilosophy
}

\author{
Charles ESS ${ }^{1}$ \\ Department of Media and Communication, University of Oslo
}

\begin{abstract}
The computational turn leads to a robo-philosophy that uses computational and robotic technologies as testbeds for philosophical questions such as the nature of being human. Robo-theology extends these approaches and interests via religious robots that further evoke questions of the mind-body, Creator-creation, and faith-reason relationships. As part of a recent agenda for non-dualistic approaches in robo-theology, Scandinavian Creation Theology (SCT) contributes a more optimistic conception of human nature and correlative non-dualistic accounts that more fully resonate with Eastern approaches. SCT is further fruitful for central issues in robo-theology such as distributed ethical agency and responsibility, love, sex, and trust.
\end{abstract}

Keywords. dualism, non-dualism, embodiment, Original Sin, Luther, Grundtvig

\section{Introduction}

I first remind us of how "the computational turn" ${ }^{[1]}$ leads to a central theme of robophilosophy - namely, a focus on robots (along with AI and affiliated technologies) as "test-beds," i.e., devices whose design and implementation allow us to explore more empirically what it means to be human vis-à-vis what we can, and cannot replicate in our machineries. What we can tentatively call "robo-theology" is then a specific extension and expansion of these interests and methods. The growing number of robots designed for religious functions and contexts specifically evokes questions concerning personhood, our relationships to nature or the created order, and the relationships between faith and reason. Specific to Christian traditions are questions of embodiment and theologies of incarnation - but we will also briefly review examples from a global range of religious traditions.

\footnotetext{
${ }^{1}$ Charles Ess, Department of Media and Communication, Postboks 1093, Blindern 0317, Oslo, Norway; e-mail: c.m.ess@media.uio.no.
} 
I then turn to a series of critiques of some of these discussions, coupled with an agenda for robo-theology. ${ }^{[2]}$ Our central point is to shift to non-dualistic approaches in contemporary scholarship, so as to overcome problematic Western attitudes towards robots and thereby enhance our resonance with important non-Western traditions.

Lastly, I introduce Scandinavian Creation Theology (SCT) as a further extension of this agenda, beginning with its more optimistic understanding of human beings and, thereby, our relationship to a nature / creation, as articulated by the defining figure of SCT, N.F.S. Grundtvig. ${ }^{[3]}$ K.E. Løgstrup's "ethical demand" then opens new possibilities and conceptual resources for addressing our possible relationships with AI / robots, most especially regarding questions of ethical agency, responsibility, and trust.

\section{From the Computational Turn to Robophilosophy}

First paragraph. The computational turn began in the 1960s and 1970s, as computers and then computer networks gradually became more available and accessible - allowing philosophers to explore traditional philosophical interests in logic, artificial intelligence, and ethics, among others. ${ }^{[1: 3]}$ Computation offered philosophers more empiricallygrounded "test beds" in which we could test theories and probe assumptions, such as theories of consciousness and cognition in AI and Artificial Life. A direct outgrowth of these extensively interdisciplinary developments has been the emergence of robotic devices, especially over the past two decades and specifically with the advent of the robophilosophy conferences. Echoing and extending earlier work and examples of the computational turn in philosophy, "robotics now gives us new, unparalleled ways of testing theories and concepts clustering around what it means to be human more broadly." ${ }^{[4: 240]}$ Robots (along with AI and affiliated technologies) serve as still more specific sorts of test-beds, as their design and implementation allow us to explore what it means to be human vis-à-vis what we can, and cannot replicate in these devices - for example, the role of embodiment in cognition, communication, and, of course, love and sex. ${ }^{[5]}$ What we can tentatively call "robo-theology" is then a specific extension and expansion of these interests - now made possible by the advent of robots such as the "U2 Blessing robot"[6] and what Trovato et al. have designated as "theomorphic robots."[7]

A first glance at these robots helps us reflect critically on both large questions concerning our personhood, as understood in diverse theologies, along with primary beliefs and assumptions regarding our relationship to nature or the created order, and, last but not least, the relationships we assume within religious traditions between faith and reason. Specific to Christian traditions are questions of embodiment and theologies of incarnation. We will see an emerging and rapidly growing literature addressing these and related issues from a wide diversity of religious traditions - both within the Abrahamic traditions of Judaism, Christianity, and Islam, as well as in such global traditions as Shinto, Daoism, Buddhism, and Hinduism.

\section{From Dualistic to Nondualistic Robophilosophy}

First paragraph. I now turn to a series of critiques of some of these discussions - primarily those of Trovato et al. ${ }^{[7]}$ - as developed in 2019 in a seminar with Ilona Nord, Jörn Hurtienne, Swantje Luthe, Diana Löffler, and Thomas Schlag. ${ }^{[2]}$ While appreciating several important insights and points made by Trovato et al - we developed an agenda 
for further reflection and discussion within robo-theology. The central theme here is a shift from the dualistic assumptions, whether explicit or implicit, at work in Trovato et al, beginning with mind-body dualisms, and extending to correlative dualistic oppositions between the human and the Divine, humanity and nature, and faith and reason. ${ }^{[3]}$ We argue instead for a shift to philosophically and theologically grounded conceptions of non-dualistic conceptions of soul-mind-body (embodiment again), of the Creator/creation relationship, and of the faith-reason relationship. Pursuing these nondualistic conceptions helps overcome problematic assumptions and beliefs about technology in general and robots in particular as dangerous and threatening (most famously, Frankenstein) that emerge in Western traditions. Doing so further brings us more in resonance with the non-dualistic traditions of especially Shinto, Daoism, and Buddhism - i.e., traditions undergirding the characteristically far more positive approaches to and appreciation of robots in general and religious robots in particular in Japanese contexts.

\section{Between Luther and Buddhism: Scandinavian Creation Theology}

\subsection{Scandinavian Creation Theology as Nondualism}

Scandinavian Creation Theology refers to contemporary theologies that draw on the Lutheran heritage as interpreted and revised by the $19^{\text {th }} \mathrm{ct}$. Danish theologian N.F.S. Grundtvig. The primary figures here are Knud Eiler Løgstrup, ${ }^{[8]}$ Regin Prenter, ${ }^{[9]}$ and Gustaf Wingren. ${ }^{[10]}$ Broadly, as the phrase "Creation Theology" signals, these traditions move in important ways beyond prevailing dualisms that instead denigrate the natural / created order. Specifically, these endorse a "non-binary view of the secular-sacred distinction." [11:17] This immediately implies that "...theology should be able to mediate between the living Christian tradition of the church and the contemporary culture in all its facets: philosophy, arts, political and natural" [11:24] - and, we can add, robots.

This non-dualism draws in part on Luther's theology of creation, in which "a Christian is also one called to live an everyday life in God's grand world of creation." ${ }^{[11: 25]}$ In contrast, however, with Luther's adherence to Original Sin, N.F.S. Grundtvig insists that "human beings never lost the positive traces of being created in the image and likeness of God." [11:25] The Creation itself "has an independent value and meaning, and is more than a mere foil for human redemption." [11:28] Contra their dualistic understandings and oppositions elsewhere, Grundtvig affirms the inextricable entanglement of God, Creation and Humankind:

Humankind ... is a unique, wonderful creation in whom divine powers make themselves known, shall develop and clarify themselves through a thousand generations as a divine experiment, which reveals how spirit and dust can interpenetrate and be clarified in a common divine consciousness. ${ }^{\text {[12:408, in 11:27] }}$

In these ways, SCT help overcome a potential difficulty for our agenda as rooted in Lutheran theology. As we have seen, while Lutheran approaches endorse the goodness of everyday life, Luther retains a commitment to the doctrine of Original Sin. Grundtvig revises this doctrine with a more optimistic understanding of human beings as retaining the basic goodness intrinsic to their status as the image of God. Stated differently: SCT thus endorses an anthropology somewhere between the Lutheran conception of human 
fallenness and a Buddhist non-dualism. The upshot is both a more optimistic understanding of human beings and, thereby, their relationship to a nature / creation where the latter is also more wholeheartedly endorsed. In these ways, SCT thus resonates even further with the underlying assumptions of non-Western traditions, thereby pointing towards a still more positive set of attitudes regarding robots, whether "secular" or religious.

\subsection{Scandinavian Creation Theology: Additional Questions for Robophilosophy}

Additional elements of SCT help both reinforce a non-dualistic approach and thereby offer new resources for formulating central questions in a robo-theology, coupled with conceptual and analytical resources for responding to these questions.

For example, especially in the work of K.E. Løgstrup, SCT endorses a non-dual relationship between faith and reason - first of all, in the domain of ethics. Løgstrup's elaboration of "the ethical demand" - as compelling for both secular and religious persons - emphasizes

an experience of the call from the other as a given reality .... The ethical demand is based on the prior fact that human beings are social beings that always live in asymmetrical relations of interdependence. Hence, we are called to take care of what is laid in our hands by vulnerable other persons. ${ }^{[11: 23]}$

This strongly relational anthropology (my term), moreover, is central to Løgstrup's highly influential account of trust. ${ }^{[13]}$ At the same time, it is more broadly shared with Prenter and Wingren as well, as a common concern characterized by Gregersen as the "humanism of the other person." ${ }^{[8: 43]}$ As well, this emphasis on relationality is still firmly conjoined with a continued insistence, inherited from Kierkegaard, on individual responsibility ${ }^{[8: 43]}$ : in this way, SCT overlaps specifically with contemporary feminist understandings of human beings as relational autonomies. ${ }^{[14]}$ This relationality forces us to extend our basic understandings of ethical agency and responsibility - specifically so as to develop conceptions of "distributed morality"[15] and "distributed responsibility"[16] that better fit our contemporary contexts as inextricably interwoven with one another in a complex of both human-human relationships as well as human-machine relationships. These machineries include the entire infrastructure of our computational technologies and communication networks - and, as a natural extension, our interactions with robots. As I have shown elsewhere, these relational forms of autonomy, morality, and responsibility directly shape our conception and understanding of the forms of ethical judgments we can and must bring to bear in these contexts. ${ }^{[17]}$ In particular, the form of reflective judgment central here and denoted as phronēsis seems not to be a capacity we can replicate via computational techniques and machineries. ${ }^{[5,18,19]}$ All of this will directly bear, obviously, on our evolving relationships with robotic devices as ethical beings, starting with broad questions of their possible agency and thereby their capacities for responsibility as distributed across our embodied and machinic networks.

In addition, Løgstrup's account of trust, as centrally resting on a philosophical anthropology emphasizing our embodiment, thereby foregrounds the critical role of our embodied co-presence with one another in order to overcome mistrust. On the one hand, this requirement helps explain the manifold difficulties of establishing trust in online communication environments as primarily disembodied: at the same time, as social robots seek to mimic human embodiment in various ways, they thereby seek, in effect, 
to meet Løgstrup's demand for embodied co-presence in order to establish trust. ${ }^{\text {[13:409] }}$ This anthropology hence directly leads to a central question in robo-philosophy and robotheology: can an AI / robot be such an "other," i.e., one who calls us to care for it as a vulnerable person - specifically as an ethical Other whom I can trust?

Briefly, this question tends to be explored in Western traditions by starting with conceptions of personhood, typically as resting on notions of self-consciousness, autonomy, ethical agency and responsibility, judgment/phronēsis and so on, as foundations for high modern conceptions of rights, duties, and responsibilities towards one another. Again, this becomes problematic for AI/robots as it is generally agreed that these capacities are lacking. ${ }^{[5,18,19]}$ At the same time, however, it is well documented that human beings easily come to care for non-humans - not only their pets, but precisely for "inanimate" entities, including (by design) robots. Broadly, such care is seen to be suspect in Western traditions (because of dualistic assumptions), while it is generally taken for granted as a positive in non-Western traditions - e.g., as manifest in such religious robots as Mindar, DarumaTO-2, and so on. ${ }^{[7]}$ As something of a third between these traditions, SCT and specifically Løgstrup's ethical demand will suggest new responses to these questions.

\section{References}

[1] Ess C, Hagengruber R. The computational turn: Past, presents, futures? Ess C, Hagengruber R, editors. The computational turn: Past, presents, futures? Conference Proceedings, IACAP (International Association of Computing and Philosophy) 25th Anniversary Conference). Münster, Germany: Heinz Nixdorf Institute, Paderborn University; 2011. p.3-4.

[2] Ess, C. Nord I, Luthe S, Schlag T, Löffler D, Hurtienne J. Seminar Paper (unpublished MS). Würzburg, 30 June 2019.

[3] Allchin A.M. N.F.S. Grundtvig: The Earth Made in God's Image. Gregersen NH, Uggla BK, Wyller T, editors. Reformation Theology for a Post-Secular Age: Løgstrup, Prenter, Wingren, and the Future of Scandinavian Creation Theology. Göttingen, Germany: Vandenhoeck \& Ruprecht; 2017. p.127-144.

[4] Ess C. Ethics in HMC: Recent Developments and Case Studies. Guzman A, editor. Human-Machine Communication: Rethinking Communication, Technology, and Ourselves. Berlin: Peter Lang; 2018. p. 237-257.

[5] Ess C. What's Love Got to Do with It? Robots, sexuality, and the arts of being human. Nørskov M, editor. Social Robots: Boundaries, Potential, Challenges. Farnham, Surrey, England: Ashgate;. 2016. p. 57-79.

[6] Luthe S, Nord I, Löffler D, Hurtienne J. Segensroboter (2019) „BlessU-2“: Forschungsimpulse für die Praktische Theologie angesichts der Entwicklung sozialer Roboter. Pastoraltheologie: Monatsschrift für Wissenschaft und Praxis in Kirche und Gesellschaft 2019 Mar; 108(3): 107-123.

[7] Trovato G, De Saint Chamas L, Nishimura M, Paredes R, Lucho C, Huerta-Mercado A, Cuellar F. Religion and Robots: Towards the Synthesis of Two Extremes, International Journal of Social Robotics, 2019. https://doi.org/10.1007/s12369-019-00553-8

[8] Gregersen NH. K.E. Løgstrup and Scandinavian Creation Theology. Gregersen NH, Uggla BK, Wyller T, editors. Reformation Theology for a Post-Secular Age: Løgstrup, Prenter, Wingren, and the Future of Scandinavian Creation Theology. Göttingen, Germany: Vandenhoeck \& Ruprecht; 2017. p. 37-66.

[9] Põder C S-V. Regin Prenter and Scandinavian Creation Theology. Gregersen NH, Uggla BK, Wyller T, editors. Reformation Theology for a Post-Secular Age: Løgstrup, Prenter, Wingren, and the Future of Scandinavian Creation Theology. Göttingen, Germany: Vandenhoeck \& Ruprecht; 2017. p. 67-89.

[10] Uggla BK. Gustaf Wingren and Scandinavian Creation Theology. Gregersen NH, Uggla BK, Wyller T, editors. Reformation Theology for a Post-Secular Age: Løgstrup, Prenter, Wingren, and the Future of Scandinavian Creation Theology. Göttingen, Germany: Vandenhoeck \& Ruprecht; 2017. p. 91-111.

[11] Gregersen NH, Uggla BK, Wyller T. Reconfiguring Reformation Theology: The Program of Scandinavian Creation Theology. Gregersen NH, Uggla BK, Wyller T, editors. Reformation Theology for a Post-Secular Age: Løgstrup, Prenter, Wingren, and the Future of Scandinavian Creation Theology. Göttingen, Germany: Vandenhoeck \& Ruprecht; 2017. p. 11-34.

[12] Grundtvig NFS. Den christelige Børnelærdom. Begtrup H, editor. N.F.S. Grundtvigs Udvalgte Skrifter, V. Copenhagen: Gyldendalske Boghandel; 1907. p. 376-737. 
[13] Ess C. Trust and Information and Communication Technologies. Simon J, editor. The Routledge Handbook of Trust and Philosophy. London: Routledge, 2020. p. 405-420.

[14] Veltman A, Piper M., editors. Autonomy, Oppression and Gender. Oxford: Oxford University Press; 2014.

[15] Floridi L. Distributed Morality in an Information Society. Sci Eng Ethics 2013 Sept; 19: 727-743. https://doi. org/10.1007/s11948-012-9413-4

[16] Simon J. Distributed epistemic responsibility in a hyperconnected era. Floridi L, editor. The onlife manifesto: being human in a hyperconnected era, London: Springer Open; 2015. p. 145-159.

[17] Ess C. Trust, social identity, and computation. Harper R, editor. The Complexity of Trust, Computing, and Society. Cambridge: Cambridge University Press; 2014. p. 199-226.

[18] Cantwell Smith B. The Promise of Artificial Intelligence: Reckoning and Judgment. Cambridge: MIT Press; 2019.

[19] Zweig K. Ein Algorithmus hat kein Taktgefühl [An Algorithm Has No Sense of Tact]. Cham, Switzerland: Springer; 2019. 